\title{
Human Development and Economic Growth in Pakistan
}

\author{
Khalid Iqbal \\ PhD Scholar, National University of Science and Technology, Islamabad, Pakistan
}

\begin{abstract}
This paper explores the relationship between human development and economic growth in Pakistan by employing the time series data ranging from 1972 to 2014. The main purpose of the research is to examine the structure of human development and its implications on economic growth in Pakistan. Human development is a crucial to social, political and economic development of a country. Human development accompanies healthier and educated people who contribute to the economic growth through their increased capabilities, skills, civil liberties, longevity, opportunities and output. Human development upsurge human proficiencies, productivity and ultimately upturn in economic growth and wellbeing. Here, the variables like life expectancy, total literacy rate and democracy are used as proxies of human development whereas econometrical methods like Unit Root Tests, Autoregressive Distributed Lag (ARDL) Cointegration Technique and Error Correction Model (ECM) are used. The findings of this paper illustrate a significant empirical relevance of human development and economic growth. Pakistan is facing the great challenge of accelerating economic growth and it requires the sustained efforts to focus and promote human development. The education and health should be given utmost eminence to reach the virtuous cycle of economic growth through the legitimate option of democracy. The prime choice is that human development should be given sequencing priority and institutional framework should be evolved to attain the ultimate goal of sustainable development.
\end{abstract}

Keywords: human development, economic growth, democracy, ADF, Autoregressive Distributed Lag (ARDL) and error correction model.

JEL Classification: F63, I15, I25, O15.

(C) The Author, 2018. This article is published with open access at Sumy State University.

\section{Introduction}

Capital includes buildings, machines, tools and capabilities of the people of a society. Jacob Mincer firstly analyzed human capital in 1958 and later on Garry Becker and T.W Schultz contributed greatly in this regard (Mincer, 1958 \& Becker, 2009). Investments on health, education and training develop the human proficiencies and then productivity of individuals. In 1990, first human development report was published by Dr. Mahbub ul Haq in a joint venture with renowned Nobel laureate Amartya Sen and other top-notch economists of that time. The report was commissioned by United Nations Development Program (UNDP).

Human development is defined as the process of advancing people's liberties and opportunities and enhancing their wellbeing. "It is about the real freedom of ordinary people have to decide who to be, what to do, and how to live" (Measureofamerica.org). Human development is an ability, personal attitude, creativity and competency, stock of knowledge, skill and experience which produce economic value and enhance the productivity (Acemoglu \& Autor, 2011). Human development is contributory to the production process through the worker's productivity which is by dint of his knowledge and skill (Becker et al., 1994). Differences in training, experience and investment in human development are cause of inter occupational gaps. Productivity increases with age and experience but when biological decline starts it decreases with age (Mincer, 1958).

Human development is very crucial for the production process and economic development of a society. In this process, all resources are transformed into a valuable paraphernalia for the humanity (Johnson, 2011). Economists are opined of that human development is very vital for the individual development, economic growth and to get rid of poverty. Economic growth is unfulfilled dream without human development because human beings accumulate capital, explore and utilize the natural resource and erect social, political and economic organizations. The human development is an elemental part of the production and economic growth (Harbinson and Myres, 1964). Lucas (1988) was the first economist who assimilated the skills that are attained through education and training in the production function.

The mental and physical capabilities acquired through education, training, skill, health care and spirituality are termed as human development (Singh, 1999). Through human development, the individuals' choices of healthier, stronger, longer and prosperous life are improved (Suri et al., 2011). Human creativity and innovations 
are productive through the technology and equipment. There is a dual causation between human development and economic growth (Suri et al., 2011). Investment in education and health boosts individual and societal development. Human development can be steered up through literacy, robustness and skill development. Human development is the development of education, skills and experience of the people (Harbinson, 1962).

Human development is a contributing factor to the economic growth whereas health and education are its elemental aspects. Healthier workers are active, robust and energetic mentally and physically. They are more productive and high earners because health and education has a direct effect on output. High life expectancies lead to older workforce with the long experience. The experience and years of schooling of workforce affect the earnings positively (Bloom et al., 2004).

The indices mainly used for human development are health, education and civil liberties which include life expectancy, literacy rate and democracy. The human development is essential for the social, political and economic development of a country and it is acquired through the knowledge, skill and training. The countries which are diffident in human development are left behind in the race of economic growth (Dauda, 2010).

Over the experience of decades, Pakistan has recognized the importance of human development. At the creation of Pakistan, situation was very dismal and still we are in want of peace, stability, prosperity, social progress and social justice. Pakistan's first generation was mainly comprised of shopkeepers, traders and merchants along with family-oriented approach. The second generation was educated, and they introduced corporate approach. In the decade of 1990's human development got the attention of governments; private sector was encouraged and professionalization was cheered.

Pakistan is in the lowest category of HDI (Human Development Index) with the value of 0.538 in 2014 at $147^{\text {th }}$ position out of 180 countries. During the years of 1980 to 2014, Pakistan's HDI value has improved from 0.353 to 0.538 and life expectancy has increased by 9.2 years (WDR, 2015).

Globalization has fostered the technological change along with low cost sources of communication as contributors to the human development and Pakistan is responding positively to the emerging scenario of opportunities and challenges. Government of Pakistan is trying to provide quality education and health to the public, technical education is being encouraged to crop the dividend of human development. Democracy is strengthening and it will grow further with the passage of time.

\section{Literature Review}

The human development is concerned with developing skills and provision of jobs to the skilled and providing productive employment for the labor force that is not being utilized. People's skills, knowledge and capabilities are enhanced through the education and training which is possible through investment (Meier, 1970). Human development is comprised of education, health and experience whereas longer life expectancy is cause of experience. Health and education directly affect the output through labor productivity and outcome of oneyear extension in life expectancy is 4 percent increase in output (Bloom et al., 2004). In developed and least developed countries, the relationship between health and per capita income is robust while fragile in the case of education. Health is very important indicator that is necessary for human development and economic growth (Knowles and Owen, 1995). There is bi-way causation between human development and economic growth. Economic growth leads to purchase of better HD where as human development determines the higher trajectory of economic growth. HD is multidimensional phenomenon but education and health are fundamental. The higher incomes and technology result in better education and longer life. The higher education enrollment, public expenditures on education and health lead to form a quality workforce which accelerates economic growth. The investing in health sector results in good health, vigor, strength and longevity. The educational levels, on job trainings, apprenticeships and other opportunities are also accentuated for the human development (Suri et al., 2011, Schultz, 1961). The research exhibits that public expenditures on education and health determine the economic growth. The relationship between human development and economic development is bi-chaining. The prioritizing of the human development leads to economic growth (Ramirez, Ranis, and Stewart, 1997). The government expenditures on health and education, enrollment in primary, secondary school and tertiary education are used as proxy for human development. In Nigeria, there is an evidence of positive correlation between human development and economic growth. The human development led to the utilization of resources, optimism, improved capabilities and resulted in an increase in economic growth. Human development is a key factor for raising living standards (Johnson, 2011). 
In the case of Pakistan, health, education enrollment and physical capital are vital to accelerate the economic growth. Education enrollment impact economic growth positively and significantly; whereas infant mortality rate impacts economic growth inversely and significantly (Ali et al., 2012). Human development fostered the technological progress and then economic growth. Human development and knowledge are accelerators to the continuous process of economic growth (Sharif et al., 2013). Education does not culminate with the completion of schooling but experience is an integral part in this regard. Training and experience mount productivity and performance. Along with expanding skill and experience earnings also expand. There is a positive correlation between investment in human development and productivity (Mincer, 1958). In case of Pakistan and Sri Lanka, enrolment in primary schools is affecting growth negatively, whereas higher school enrolment is impacting economic growth positively and significantly. Education is an important contributor to human development, productivity and positive economic effects (Abbas, 2001).

\section{Theoretical Background}

The importance of schooling, skill development and training is undeniable and it is expedient of the disequilibrium conditions (Schultz, 1960 \& 1961). Education and training improve the decision making, productivity of people and adoption of new technologies (Johnson, 2011).

Education increases efficiency, skill and productivity. Investment in education enriches the faculties of human being, upsurges the productivity of workers and ultimately upturn in economic growth. Education changes attitudes and values which affect individuals itself and society throughout the life. The educational expansion develops a labor force that is more skilled and more productive.

The neo-classical model exhibits the technical growth or productivity of factors along with other factors. Mankiw, Romer and Weil model assimilated human capital effects on economic growth in their model and found that there is a robust and positive association between investment in human capital and growth of output. Lucas termed human capital as the stock of knowledge that is acquired by studying the textbooks, scholarly journals and websites (Mankiw, 1995). Lucas also introduced the concept of externalities to human capital as a person is more productive when he is accompanied by the persons who are equipped with the high levels of human capital. Solow's showed that human capital is boundless and with no diminishing returns.

\section{Objectives of the study}

$>$ To evaluate impact of human development on economic growth.

$>$ To examine the structure of human development and its trend.

$>$ To determine the means of human development.

$>$ To recommend policy suggestions.

\section{Data and Econometric Methodology}

All series examined in this study - GDP per capita Income, Life Expectancy, Literacy Rate and Democracy are taken from WDI, A Hand Book of Statistics, Economic Survey of Pakistan and Polity IV. The data of Pakistan is annual and it spans over the period 1972 to 2014. The model developed to check the impact of human development on economic growth of Pakistan is based on economic theory.

$L G D P=\beta_{0}+\beta_{1} L E+\beta_{2} T L R+\beta_{3} D E M+\mu$

Where terms LGDP, LE, TLR, DEM and $\mu$ represent the Log of Gross Domestic per capita Income (in rupees), Life Expectancy (in years), Total Literacy Rate, Democracy and error term. LGDP is a measure of economic growth and wellbeing. Life Expectancy is an individual's expected years of life and it is affected by heredity, nutrition, health conditions and occupation. Life expectancy is an indicator of health and experience. Total literacy rate embodies the knowledge and skill whereas democracy symbolize civil liberties and governance. Democracy creates an environment of wellbeing and political freedom. Life expectancy, total literacy rate and democracy are used as the proxies of human development.

This research adopts the autoregressive distributed lag (ARDL) framework by Pesaran and Shin $(1995,1999)$, Pesaran et al. (1996) and Pesaran (1997) to find out the long run relationship between variables. The ARDL approach to co-integration is applied if variables are stationary with different orders as I (0), I (1) or Mixture of both as I (0) and I (1). The ARDL model is based on single equation; it is appropriate and efficient for the small sample sizes and computations. ARDL approach to co-integration also gives unbiased results for the long run models (Harris and Sollis, 2003). The ARDL model uses the lags of explanatory variables and 
addresses the problem of endogeniety. It is used to estimate the long run coefficients and standard errors by applying Akaike Information Criterion (AIC) or Schwarz Information Criterion (SIC) and Schwarz Information Criterion (SIC) is consistent and slightly better in performance (Pesaran and Shin, 1997).

The general form of ARDL equation for estimation:

$$
\begin{aligned}
\Delta L G D P=\beta_{0} & +\sum_{i=1}^{n} \beta_{i} \Delta L E_{t-i}+\sum_{i=1}^{n} \beta_{i} \Delta T L R_{t-i}+\sum_{i=1}^{n} \beta_{i} \Delta D E M_{t-i}+\delta_{1} L E_{t-1}+\delta_{2} T L R_{t-1} \\
& +\delta_{3} D E M_{t-1}+\mu_{t}
\end{aligned}
$$

Here $\Delta$ is the first-difference operator and $n$ is the optimal lag length. For the lag length we used general to specific rule and have taken four lags for our ARDL specification.

The bound testing (ARDL) is applied to find the long run relationship between the variables. The $\mathrm{F}$ test is for excluding the multiple restrictions and it indicates that which variable should be normalized. $\mathrm{F}$ test is for the overall significance of regression and under null hypothesis explanatory variables are not impacting dependent variable. The null hypothesis for no co-integration among variables in the equation is $\mathrm{H}_{0}: \delta_{1}=\delta_{2}=\delta_{3}=0$ against the alternative hypothesis $\mathrm{H}_{1}: \delta_{1} \neq \delta_{2} \neq \delta_{3} \neq 0$. Where $\mathrm{H} 0$ states no integration and $\mathrm{H} 1$ states that co-integration exists. Pesaran et al (2001) tabulated two critical values for the co-integration test. The lower critical bound assumes all variables are I (1) while upper bound assumes that they are I (0). When the calculated F-static is above the upper bound critical value then null hypothesis is rejected and it indicates co-integration. If F-static falls below the lower bound critical value, then null hypothesis cannot be rejected which shows the lack of cointegration. When calculated $\mathrm{F}$ value is with in the lower and upper bound then result is inconclusive.

The ARDL specification of the short-run dynamics can be derived by constructing an error correction model (ECM) of the following form:

$$
\begin{aligned}
\Delta L G D P=\beta_{0}+ & \sum_{i=1}^{n} \beta_{i} \Delta L E_{t-i}+\sum_{i=1}^{n} \beta_{i} \Delta T L R_{t-i}+\sum_{i=1}^{n} \beta_{i} \Delta D E M_{t-i}+\delta_{1} L E_{t-1}+\delta_{2} T L R_{t-1} \\
& +\delta_{3} D E M_{t-1}+\emptyset_{0} E C M 1_{t}+V_{t}
\end{aligned}
$$

The Error Correction Mechanism (ECM) measures the effect of one-time series on another and corrects the error in another. ECM is applied to study the short run dynamics of the model. ECM also measures the speed of return or adjustment to equilibrium after deviation (Shittu et al, 2012). The ECM model also contains an error correction term which adjusts two I (1) series back into long run equilibrium (Wooldridge, 2015). This adjustment process prevents the errors in the long run relationship from becoming larger and larger.

\subsection{Estimation and Results}

First, we find out whether data series is containing trend or not. Dickey Fuller devised a procedure for testing the unit root. Augmented Dickey Fuller (ADF) test is used to check the stationarity level of the variables. ADF test consists of Autoregressive AR (1) and takes an extra lag in terms of the dependent variable in order to eradicate the autocorrelation. Null hypothesis $(\mathrm{H} 0)$ of unit root is tested against the alternate hypothesis $(\mathrm{H} 1)$ of no unit root at level and 1st difference.

Table 1. Results of Unit Root Test

\begin{tabular}{|l|c|c|c|c|}
\hline \multirow{3}{*}{ Variable } & \multicolumn{3}{|c|}{ ADF Test Statistic (with trend and intercept) } \\
\cline { 2 - 5 } & \multicolumn{3}{|c|}{ Level } & \multicolumn{2}{c|}{ First Difference } \\
\cline { 2 - 5 } & Test Statistics & Critical Value & Test Statistics & Critical Value \\
\hline$L G D P$ & -1.514542 & -4.198503 & -5.021562 & $-4.198503^{* * *}$ \\
\hline$L E$ & -3.181257 & -4.243644 & -4.012959 & $-3.533083^{* *}$ \\
\hline$T L R$ & 0.089036 & -4.192337 & -5.294508 & $-4.198503^{* * *}$ \\
\hline$D E M$ & -23.68497 & $-4.192337 * * *$ & -41.47235 & $-4.198503^{* * *}$ \\
\hline
\end{tabular}

Note: *** Significant at $1 \%$ level. ** Significant at 5\% level. * Significant at $10 \%$ level.

In the above table LGDP, LE, TLR are stationary of order I (1) and DEM is stationary of order I (0) so that we apply ARDL.

The ARDL results are given in the following table. 
Sample (adjusted): 19762014.

Included observations: 39 after adjustments.

Table 2. The ARDL Results of the Model

\begin{tabular}{|l|c|c|c|c|}
\hline Variable & Coefficient & Std. Error & t-Statistic & Probability* \\
\hline C & 0.783841 & 0.453186 & 1.729622 & 0.0951 \\
\hline LGDP(-1) & 0.509834 & 0.167903 & 3.036486 & 0.0053 \\
\hline LE & 0.965433 & 0.335317 & 2.879163 & 0.0077 \\
\hline LE(-1) & -2.805932 & 0.926405 & -3.028840 & 0.0054 \\
\hline LE(-2) & 2.664688 & 0.917414 & 2.904564 & 0.0073 \\
\hline LE(-3) & -0.797500 & 0.325811 & -2.447740 & 0.0212 \\
\hline TLR & 0.000310 & 0.001400 & 0.221105 & 0.8267 \\
\hline TLR(-1) & -0.000521 & 0.001771 & -0.294358 & 0.7707 \\
\hline TLR(-2) & 0.000591 & 0.002087 & 0.282946 & 0.7794 \\
\hline TLR(-3) & -0.000466 & 0.002215 & -0.210626 & 0.8348 \\
\hline TLR(-4) & -0.002984 & 0.001593 & -1.873190 & 0.0719 \\
\hline DEM & 0.001337 & 0.000556 & 2.403504 & 0.0234 \\
\hline
\end{tabular}

\begin{tabular}{|l|c|c|c|}
\hline R-squared & 0.997655 & Mean dependent var & 4.605855 \\
\hline Adjusted R-squared & 0.996700 & S.D. dependent var & 0.103929 \\
\hline S.E. of regression & 0.005971 & Akaike info criterion & -7.156260 \\
\hline Sum squared resid & 0.000963 & Schwarz criterion & -6.644395 \\
\hline Log likelihood & 151.5471 & Hannan-Quinn criter. & -6.972607 \\
\hline F-statistic & 1044.245 & Durbin-Watson stat & 2.057457 \\
\hline Prob(F-statistic) & 0.000000 & & \\
\hline
\end{tabular}

*Note: p-values and any subsequent tests do not account for model selection.

Table 3. The Long-Run Model

\begin{tabular}{|l|c|c|c|c|}
\hline \multicolumn{5}{|c|}{ Long-Run Coefficients } \\
\hline Variable & Coefficient & Std. Error & t-Statistic & Prob. \\
\hline C & 1.599134 & 0.450654 & 3.548471 & 0.0014 \\
\hline LE & 0.054451 & 0.009346 & 5.826128 & 0.0000 \\
\hline TLR & -0.006267 & 0.002626 & -2.386839 & 0.0243 \\
\hline DEM & 0.002727 & 0.000810 & 3.365338 & 0.0023 \\
\hline
\end{tabular}

In these results, we see that one-unit increase in life expectancy contributes 5\% to the GDP per capita in the long run. LE is affecting per capita GDP positively and significantly. There is a strong and robust relationship between life expectancy and per capita income (Knowles and Owen, 1994, Isola and Ilani, 2012). The rise in life expectancy leads to rise in savings then economic growth through investment. The longer life expectancy also encourages investment in human capital and then ultimately increases the economic growth (Salman, 2015).

Democracy also raises economic growth significantly, on unit increase in democracy results in $2 \%$ increase in the economic growth. Democracy has played a very conducive role in the human development (Qureshi, 2012). The results coincide with many political economists who argued that democracy fosters the economic growth (Brunetti, 1997; Keech, 1995; Preziworski et al., 1996 and Remmer, 1995). The institutions that are more auspicious for growth get mature in democracy (Kormendi and Meguire, 1985; Knack and Keefer, 1995; and World Bank, 1997). Democratization has feedback effects through political stability and higher rates of investment which faster economic growth (McMahon, 1999, p. 92). Democracy has direct and indirect effects on economic growth via secondary education and life expectancy (Baun and Lake, 2003). So democracy is a crucial element of human development which positively affects the economic growth (Baun \& Lake, 2003; Gerring et al., 2004; Rigbon and Rodrik, 2004).

Total literacy rate marks negative effects on economic growth significantly. Increase of one unit in TLR leaves $0.6 \%$ decrease on per capita income. The effect of education on economic growth in developed countries is not significant, null and even negative (Islam, 1995; Barro, 2001). One reason for this puzzle is that human 
capital is not exchanged in markets. It is measured through education indicator and there is measurement error and heterogeneity (Coulombe and Tremblay, 2016). The studies of Benhabib and Spigel (1994) and Pritchett (2001) also capture the negative effects of education on economic growth of countries. The gender gap in education and economic growth has negative relationship (Galor and Weil, 1996; Knowles et al., 2002). This study's negative results on total literacy rate also accord with the results of Barro (1991), Cselli et al. (1996) Coullombe and Tremblay on education. Education, itself is not a guarantor of worthwhile development and its evident examples are former Soviet Union, Sri Lanka, Philippines and Indian State Kerala and West Bengal. In most of the countries unequal distribution of the education has left the negative impact. In Pakistan middle school enrollment has negative impact on real GDP (Kiani, 2009). Inequality in distribution of education negatively and robustly impact economic growth (Birds Sall and Londono, 1997). Education has no some economic impact in every country. Educational effect is strongly negative and significant mainly due to perverse governance, decreasing marginal returns to education, difference in supply and demand of education that has created no human capital (Filmer et al., 2002). World Development Report also mentioned the lack of relationship between expansion of education and economic growth. The negative impact of education on economic growth in Africa, MENA, Non-OECD and other countries has also been observed (Lan et al., 1991; Lavy, 1992; Behram, 1987; Dasgupta and Weale, 1992).

To see if there is any long relationship between human development and economic growth, we need to test the joint significance of coefficient LGDP and that of interaction term. For this purpose, we will use the WALD Coefficient Restriction Test. The results are as follows.

\subsection{Wald Test}

The Wald test is a parametric statistical test and it was envisaged by Hungarian statistician Abraham Wald. This test can be used to test the true value of the parameter based on the sample estimate.

Table 4. Equation untitled

\begin{tabular}{|l|c|c|c|}
\hline Test Statistic & Value & df & Probability \\
\hline F-statistic & 3.338531 & $(9,27)$ & 0.0072 \\
\hline Chi-square & 30.04678 & 9 & 0.0004 \\
\hline
\end{tabular}

Null hypothesis: $C(2)=C(3)=C(4)=C(5)=C(6)=C(7)=C(8)=C(9)=C(10)=0$

\begin{tabular}{|l|c|c|}
\hline Normalized Restriction $(=0)$ & Value & Std. Err. \\
\hline $\mathrm{C}(2)$ & 0.965433 & 0.335317 \\
\hline $\mathrm{C}(10)$ & -0.002984 & 0.001593 \\
\hline
\end{tabular}

We will now compute the F-stat of Wald test with Pesaran (2001) critical values. The Pesaran (2001) critical values are significant at $5 \%$ level.

Table 5. Results of Bound F-testing

\begin{tabular}{|c|c|c|}
\hline \multicolumn{2}{|c|}{ Critical values at 90\% level of significance } & F-calculated \\
\hline Lower bound $\mathrm{I}(0)$ & Upper bound $\mathrm{I}(1)$ & 3.319403 \\
\hline 2.37 & 3.2 & \\
\hline
\end{tabular}

The bound test involves asymptotic critical value bounds, depending on whether the variables are I ( 0 ) or I (1) or a mixture of both. Two sets of critical values are generated which one set refers to I (1) series and the other for I (0) series. Critical values for I (1) series are referred to as upper bound critical values; while the critical values for I (0) series are referred to as the lower bound critical values. The Bound co-integration test depict that there exists a long run co-integration between human development and economic growth in Pakistan.

Now, we find the short run estimates of our model by running the ECM model. 
Table 6. The ECM Model Results

\begin{tabular}{|l|c|c|c|}
\hline Variable & Coefficient & t-Statistic & Prob. \\
\hline ECM_1 & -0.110563 & {$[-2.09133]$} & $(0.05287)$ \\
\hline$\Delta$ LE & $0.057122 *$ & {$[2.05247]$} & $(0.02783)$ \\
\hline$\Delta$ TLR & -9.240538 & {$[-1.51513]$} & $(6.09886)$ \\
\hline$\Delta$ DEM & 19.27197 & {$[1.18909]$} & $(16.2073)$ \\
\hline
\end{tabular}

*Shows the $1 \%$ significance of coefficients.

The CECM_1 term is negative and significant. It shows that our system has a tendency to converge to the equilibrium. The coefficient exhibits that almost $11 \%$ of the shock in equilibrium growth is adjusted in the first year. This shows that our model takes less than 9 years to come back to equilibrium whenever there is a shock in our system. In short run life expectancy is affecting per capita income positively and significantly while democracy positively and insignificantly. On the other hand total literacy rate has a negative and insignificant impact on the per capita income in the short run.

\subsection{Diagnostic Tests}

In this sub-section we run the different diagnostic tests to see if our ARDL model is free from autocorrelation, heteroscedasticity and model misspecification. We will also run CUSUM and CUSUM square charts to see the stability of parameters.

\subsection{Testing for Autocorrelation}

We run the serial correlation LM test to see if our model has serial correlation. The results are as follows:

Table 7. LM Test Results

\begin{tabular}{|c|c|}
\hline LM-Stat & Probability \\
\hline 36.21728 & 0.0027 \\
\hline
\end{tabular}

The results show that our model is free from autocorrelation problem because we cannot reject the null hypothesis of no autocorrelation.

\subsection{Testing for Heteroscedasticity}

To test for heteroscedasticity, we run Breusch-Pagan-Godfrey test and results are as following:

Table 8. Results of the Heteroscedasticity

\begin{tabular}{|l|c|c|c|}
\hline \multicolumn{3}{|l|}{ Heteroscedasticity Test: Breusch-Pagan-Godfrey } & Prob. F(11,27) \\
\hline F-statistic & 0.515614 & Prob. Chi-Square(11) & 0.8758 \\
\hline Obs*R-squared & 6.770328 & Prob. Chi-Square(11) & 0.8174 \\
\hline Scaled explained SS & 2.381689 & & 0.9966 \\
\hline
\end{tabular}

\subsection{Stability of the Model}

The stability of the model is very important issue and unstable model does not remain valid in the testing circumstances. The CUSUM and CUSUMSQ tests are applied to assess the stability of the model (Pesaran et al 1997) and these tests were developed by Brown et al (1975). These tests are cumulative sums and sums square of residuals that are plotted against time. The hypothesis of the test is as following: H0: All coefficients are stable in the model H1: All coefficients in the model are not stable. Plots of CUSUM and CUSUM Q are within the boundaries, if the plot line does not crosses the boundary at any level then accept the Null hypothesis and reject the alternative hypothesis. If the plot line crosses the boundary at any level then reject the null hypothesis and accept the alternative hypothesis. Both the plots show that line within the boundaries at 5 percent significance level. Therefore these tests reveal that model is stable and accept the Null hypothesis. 


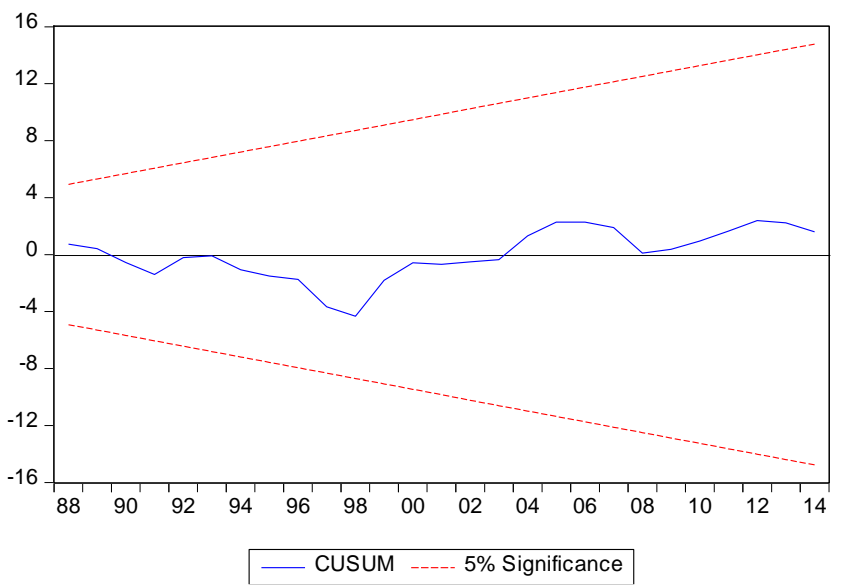

Figure 1. CUSUM statistics

In this figure CUSUM statistics fall within the 5\% significance level.

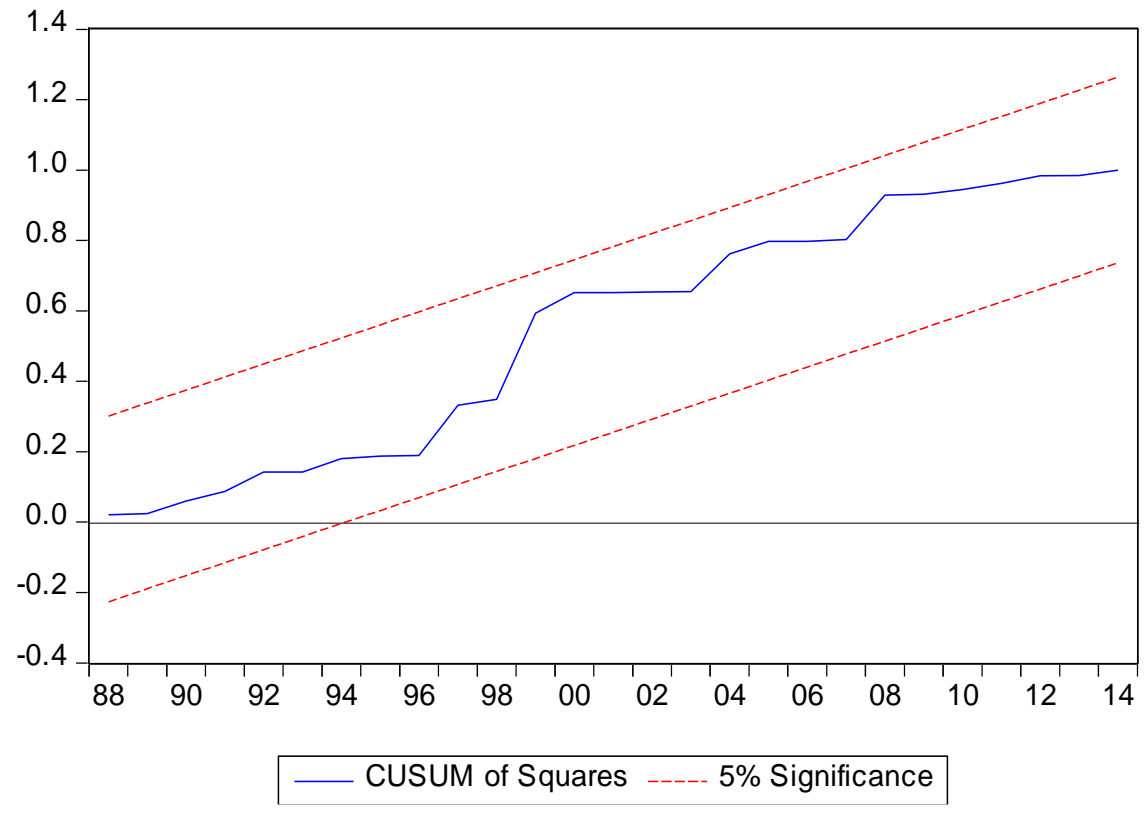

Figure 2. CUSUMSQ statistics

The figure shows that the plots of CUSUM and CUSUMSQ statistics are well existed within the critical bounds and implying that all coefficients of the short run model (ECM) are stable.

\section{Conclusions and Recommendations}

This paper has shown that economic growth in Pakistan is closely related with human development. To augment this study many econometrical tools like unit root tests, ARDL and ECM (Error Correction Model) are used. The results suggest that there is a long run positive and significant relationship between GDP per capita and human development proxies like life expectancy and democracy while total literacy rate has negative and significant effect in Pakistan. As we know that Pakistan is facing the great challenge of accelerating economic growth and it requires the sustained efforts to promote human development. Thus the suggested policy implications of this study are that government should prioritize the education and health and promote the democracy in the country. The technical and objective oriented education increase skill, productivity and economic growth. Female education should be prioritized by the government because it also contributes to lowering the infant mortality rate. Women productivity also transfers to the next generation also. Educational development expenditures should be increased and investment in human capital should be encouraged. Educational inequalities like, provincial, urban rural, male female and rich poor should be removed. Government should increase the health expenditures because good health brings prosperity to individuals and increases their productivity and ultimately economic growth. Health services infrastructure should be promoted, availability of clean water and hygienic food should be ensured and exercise culture should be promoted for further longevity of life. 
Democracy is life line for Pakistan and legitimate option for human development. It should be nurtured and its continuity should be ensured for its pure form to reach the virtuous cycle of economic growth.

\section{References}

1. Abbas, Q. (2001). Endogenous Growth and Human Capital: A Comparative Study of Pakistan and Sri Lanka. The Pakistan Development Review, 40(4), 987-1007.

2. Acemoglu, D., \& Autor, D. (2011). Lectures in labor economics. Manuscript. Available at: http://economics.mit. edu/files/4689.

3. Becker, Gary S. (2009). Human capital: A theoretical and empirical analysis, with special reference to education. University of Chicago press.

4. Birdsall, N., \& Londono, J. (1997). Asset Inequality Does Matter: Lessons from Latin America. Research Department Publications 4066, Inter-American development Bank, Research Department.

5. Bloom, D. E., D. Canning, and J. Sevilla (2004). The Effect of Health on Economic Growth: A Production Function Approach. World Development, 1-13.

6. Dasgupta, P., \& Weale, M. (1992). On measuring the quality of life. World Development, 20(1), 119-131.

7. Dauda Risikat O. S. (2010). Role of Human Capital in Economic Development: An Empirical Study of Nigerian Case.

8. Engle, R. F. and Granger, C. W. J. (1987). Co-integration and error correction: Representation, estimation and testing. Econometrica, 55, 251-276.

9. Filmer, D., Hammer, J. S., \& Pritchett, L. H. (2002). Weak links in the chain II: a prescription for health policy in poor countries. The World Bank Research Observer, 17(1), 47-66.

10. Globalisation and sustainability: environmental Kuznets curve and the WTO. Ecological Economics, 39, 185-196.

11. Harbinson, F. H. (1962). Human resources development planning in modernizing economies. International Labor Review, 453-458.

12. Harbinson, F. H. and Meyers, A. C. (1964). Education, Manpower, and Economic Growth: Strategy of Human Resource Development. McGraw Hill Book Company, USA.

13. Harris, R. I. D., \& Sollis, R. (2003). Applied time series modelling and forecasting. Chichester, West Sussex: Wiley.

14. Johnson, A. O. (2011). Human Capital Development and Economic Growth in Nigeria. European Journal of Business and Management, 3(9).

15. Knowles, S. and Owen, P. D. (1995). Health capital and cross-country variation in income per capita in the Mankiw-Romer-Weil model. Economics Letters, 48, 99-106.

16. Lucas, R., E. Jr. (1988). On the Mechanics of Economic Development. Journal of Monetary Economics 22, 3-4.

17. Measureofamerica.org.

18. Mincer, J. (1958). Investment in human capital and personal income distribution. The journal of political economy, 281-302.

19. Pesaran, M.H. (1997), The Role of economic Theory in Economic Modelling the Long Run. The Economic Journal, 107, 178-191.

20. Pesaran, M., \& Shin,Y. (1999). An Autoregressive Lag Modeling Approach to Cointegration Analysis. In S. Strom (ed.) Econometrics and Economic Theory in 20th Century: The Ragnar Frisch centennial Symposium, Cambridge University Press, Cambridge.

21. Pesaran, M. H., Shin, Y., \& Smith, R. J. (2001). Bounds Testing Approaches to the Analysis of Level Relationships. Journal of Applied Econometrics, 16, 289-326.

22. Ramirez, A., Ranis G., and Stewart, F. (1997). Economic Growth and Human Development. Center Discussion Paper No. 787.

23. Sharif, T., Ahmed, J., Abdullah, J,. (2013). Human Resource Development and Economic Growth in Bangladesh: An Econometric Analysis. European Journal of Business and Management, 5(7).

24. Sajid Ali, Imran Sharif Chaudry \& Fatima Farooq (2012). Human capital formation and economic growth in Pakistan. Pakistan Journal of Social Sciences, 32(1), 229-240.

25. Schultz, T. P. (1992). The role of education and human capital in economic development: An empirical assessment. E. G. Center, \& C. New Haven (Eds.). Economic Growth Center, Yale University.

26. Schultz, T. W. (1961). Investment in Human Capital. American Economic Review, pp. 1-17. 
27. Singh, K. (1999). Rural Development: Principles, Policies and Management. 2nd edition, Sangha Publications, India Ltd, New Delhi.

28. Shittu, O. I., Yemitan, R. A., Yahya, O. S. (2012). On Autoregressive Distributed Lag, Cointegration and Error Correction Model [An Application to Some Nigeria Macroeconomic Variables]. Australian Journal of Business and Management Research, 2(8), 56-62.

29. Suri, T., Boozer, M. A., Ranis, G., Stewart, F. (2011). Paths to success: the relationship between human development and economic growth. World Development, 39, 506-522.

30. Sjö, Bo (2012). Testing for Unitroots and Cointegration. Available at: http://www.iei.liu.se/nek/ekonometrisk-teori-7-5-hp-730a07/labbar/1.233753/dfdistab7b.pdf (Erişim Tarihi: 26 Aralık 2012).

31. Meier, G.M. (1970). Leading Issues in Economic Development. $2^{\text {nd }}$ Ed. Oxford: Oxford University Press

32. Wieland, S., Lan, N. C., Mirasedeghi, S., \& Gee, K. W. (1991). Anxiolytic activity of the progesterone

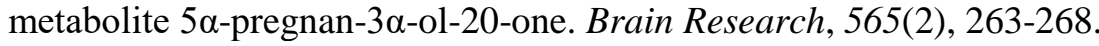

33. World Bank Group (2015). World Development Report 2015: Mind, Society and Behavior. Washington, DC: World Bank. 